ルコール $(10 \mathrm{~m} l)$ にとかしアニリン $(0.75 \mathrm{~g})$ を加え 4 版間還流 䅈洲し，のち常温に 1 夜放㯰して $0.20 \mathrm{~g}$ の結晶を得た。 $\mathrm{mp} 164^{\circ}$

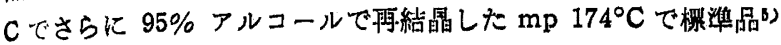
との浬融ては融点の降下走さない。 $[\alpha]_{\mathrm{D}}^{7}-101.2^{\circ}$ ( 7 分) 一 $-40.1^{\circ}(24$ 洔間, アセトン c $0.95 \%)$

分析値 C $60.55 \%, \mathrm{H} 7.48 \%, \mathrm{~N} 4.85 \%$, $\mathrm{OCH}_{8} 30.61 \%$

$\mathrm{C}_{8} \mathrm{H}_{8} \mathrm{O}_{2}\left(\mathrm{OCH}_{8}\right)_{8} \cdot \mathrm{NHC}_{6} \mathrm{H}_{5}$ としての

$$
\begin{aligned}
& \text { 断筑健 C } 60.6 \%, \mathrm{H} 7.7 \% \text {, N } 4.7 \% \text {, } \\
& \mathrm{OCH}_{3} 31.31 \%
\end{aligned}
$$

画分 IV Seliwanoff のケトースの反応を示し, またそのペー パークロマトグラムはメチル-2-Oーメチル-3,6-アンヒドローLーガ ラクトシッドに相当少るハン点を与える。画分 IV $0.459 \mathrm{~g}$ を $1 \mathrm{~N}$ 硫酸 $10 \mathrm{ml}$ と $98^{\circ} \mathrm{C}$ に 5 㭙間加熱し，その生成物を炭破バ リウムで非和したのちロ液を滥縮し，アセトンで抽屹して 0.313 g のシラップを得た。これはペーパークロマトグラフィーによ. って 5-ヒドロオキシメチルフルフラールと 2,4,6-トリ-O-メチ ルーDーガラクトースとに一敘する2 個のハン点を与える。したが つてもとの画分 $\mathbb{N}$ はメチ 2-O-メチル-3,6-アンヒドロ-L-ガラ クトシッドとメチル-2, 4,6-トリーO-メチルーDーガラクトシッドの 洩合物であって水解によって前者が分解したことがわかる。その 制合は分解物の収量から，前者約 30\% にたいし後者 70\% であ る。

な山裴 2 の画分 $\mathbb{X}$ およびX はそれぞれ 15\%エタノールおよび
25\%エタノールで渵出されたもので二㯇類のメチル置換体と思わ れるが後日の研究に讓ることにした。

\section{6 石油エーテル可溶成分}

石油エーテル可溶成分 $0.123 \mathrm{~g}$ を石油エーテル( bp $40^{\circ} \sim 45^{\circ}$ C) で抽此してそれから $57 \mathrm{mg}$ の結晶を得た。 $\mathrm{mp} 62^{\circ} \sim 63^{\circ} \mathrm{C}$ ， $[\alpha]]_{\mathrm{D}}+64.78^{\circ}$ (水, $c 1.20 \%$ )で，その分析值はメチル 2,4,6トリーーーメチルーローガラクトピラノシッド円 とよく一致する。

分析値 C $50.10 \%, \mathrm{H} 8.20 \%, \mathrm{OCH}_{8} 52.36 \%$ $\mathrm{C}_{6} \mathrm{H}_{8} \mathrm{O}_{2}\left(\mathrm{OCH}_{8}\right)$ ）としての

斯算值 C $50.85 \%, \mathrm{H} 8.47 \%, \mathrm{OCH}_{8} 52.54 \%$ 上の絈晶の口液は Seliwanoff のケトース反応を示し, 水飽和 のシクロヘキサノールを展開刹，O-アミノフェノール/リン酸アルコールを発色用としてペーパークロマトグラフィーを行なう とき $R_{f} 0.77$ (カッ色)と 0.84 (カッ色) の 2 個のハン点を示す。

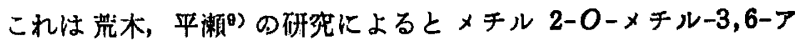
ンヒドロ-Lーガラクトシッドとメチル 2,4-ジーO-メチル-3,6-ア ンヒドローレーガラクトシッドとに一致するが畞料の㑤少のため確 定的な柾明を行なうことができなかった。

本研究は, 京都大学理学部田中正三数授と京都工芸緙維大学工 芸学部荒木長次教授の終始琶第なる御指導のもとに行ない, 周到 なる御校酊を睛わりました。既往 30 年の久しきにわたる雨先生

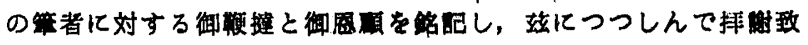
します。

\title{
秋田座あ加根の含有色萩
}

(昭和 36 年 5 月 29 日受理)

商 豊†

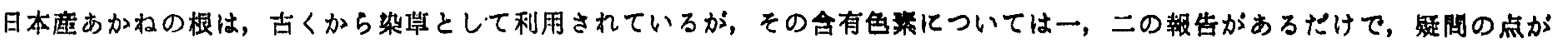
少なくない。

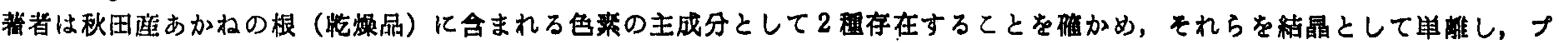
ルプリン，打よびムンシステンであるととを值鳃した。

\section{1 緒}

古代に染韩としてしばしば利用されていたあかね厥植物の根の

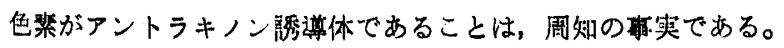
日本庭あかね(Rubia cordifolia var munjista Miq.)の根も古く から染料として利用されていたが，その含有色䋕については初 近滕】によってプルプリン(I) が抽出され，和田2)によってプソ

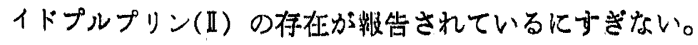

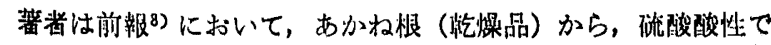
エタノールによって抽性される色攀に，二つの成分が含まれてい ることをあきらかにしたが，今回，その二色䋈の結畾を単雃し，

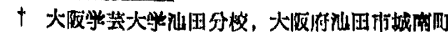

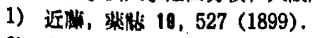

2) 和田，和快 $11 ， 416$ (1941).

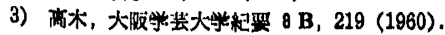

その一つがプルプリンであることを同定し，他はムンジスチン(I) であることを碓認したのでここに報告する。<smiles>O=C1C(O)CC(O)C(O)C(=O)C2CCCCC12</smiles>

(I)<smiles>O=C1C2CCCCC2C(=O)C2C1CC(O)C(C(=O)O)C2O</smiles>

(II)<smiles>O=C(O)C1C(O)C(O)C2C(=O)C3CCCCC3C(=O)C2C1O</smiles>

(I)<smiles>O=C1C2CCCCC2C(=O)C2C(O)CC(O)CC12</smiles>

(IV)
四 1 アントラキノン色慗の粠造式 


\section{2 実験}

\section{1 あかね根に含有される色素の定性}

前報》に記したように，秋田産あかね根には 2 種の色素の存在 が証明される。この 2 種の色素の定性のため, 乾燥あかね根を水 洗後, $2 \%$ 硫酸 20 容, $95 \%$ エノール 80 容の混合物で加熱抽 出してえられる赤橙色の抽出液を, 湯浴上で淃縮してェタノール を除去し，冷却後析出する赤色沈殿をロ別し，これをふたたびエ タノールに溶解したものを試料としてペーパークロマトグラフィ 一を行なった。すなわち，紙として東洋沪紙 No. 50 をもち い, ブタノール・酢酸・水(容量比, $4: 1: 1$ ) で展開すれば, $R_{f}$ 0.90 に赤, $R_{f} 0.50$ に黄の二つのハン点が認められた。 $R_{f} 0.90$ （赤）のハン点を与える色素を $\mathrm{R}, R_{f} 0.50$ (黄) の色素を $\mathrm{Y}$ と略 記すると，秋田産あかね根の抽出液にはこのRおよびY以外の色 素の存在は認められない。 $\mathrm{R}$ 色素の $R_{f}$ 值はプルプリン標品*1の それと一致しており，この条件ではアリザリンもまた，ほとんど 同じ $R_{f}$ 值(0.89) を示すが，前報3) で述べたように，この試料 はアリザリンを含んでいないので， R はプルプリンであると推定 される。また，京都産あかね根（新鮮品）を材料として，まった く同様に行なった実験の結果も，RおよびYの二色素の存在だけ が認められた。

2.2.1Y色秦の単離とその確認: 選別した秋田産あかね根（乾 燥品） $50 \mathrm{~g}$ を粗砝し，これを 2.1 に記した硫酸・エタノール混合 液 $300 \mathrm{~m} l$ とともに, 還流冷却器下, 沸騰水浴上で 2 時間加熱抽 出して抽出液を傾鴧し, 残留物には新しい溶媒を加えてさらに 2 回同様に抽出する。抽出液は合せて口過し, 常圧でエタノールを 留去すると赤褐色沈殿の㲘濁した液がえられる。これをエーテル で抽出すると色素はほとんど全部エーテル層に移る。橙色のエー テル層を数回水洗したのち， $2 \%$ 酢酸ナトリウム水溶液を加えて 抽出すると色素の一部は水層に移る。新しい酢酸ナトリウム溶液 ととりかえながら, 水層がほとんど着色しなくなるまでこの抽出 をくりかえす。

この酶酸ナトリウム抽出液は合して，6N 硫酸を加えて強酸性 とし一晚放置すると, 黄色の無定形沈殿を生じる。沈殿は少量の 熱×タノールに溶解し, 熱時口過したのち，等量の水を加え, さ らに $6 \mathrm{~N}$ 硫酸を加えて強酸性とし, 生じる沈殿を加熱していった ん溶解させたのち, 放冷すると微細な橙黄色の結晶が析出する。

この色素結晶を試料として，2.1に記したブタノール・酢酸 水を溶媒とするぺーパークロマトグラフィーを行なうと，単一の 黄色のハン点だけを与え,その $R_{f}$ 值は前述のY色素と一致する。 この粗結晶を硫酸酸性にした含水メタノールから再結晶して黄 色針状結晶䄪 $100 \mathrm{mg}$ がえられたが，その融点は $230^{\circ} \mathrm{C} * 2$ であ った。この結晶をさらに少量の熱水酢酸に溶解し, 放泠して再結 晶すると, 橙黄色薄片状結晶として析出する。このものの融点は $234^{\circ} \mathrm{C}$ で,元素分析の結果はつぎのようにムンジスチン $\left(\mathrm{C}_{15} \mathrm{H}_{8} \mathrm{O}_{6}\right)$ としての計算值によく一致している。

\section{表 1 Y色素の炭水素分析值（\%)}

試料 $2.7766 \mathrm{mg}$

$\mathrm{CO}_{2} 6.4332$ "

$\mathrm{H}_{2} \mathrm{O} \quad 0.7290 "$
C $\quad 63.18$

$\mathrm{H} \quad 2.935$
計算值

63.29

2.84
*1 東京化成分析用特級获蓝を用いた。

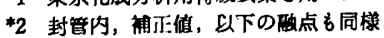

2.2.2 Y色素の脱岩酸: このY色素がムンジスチン(II) であれ ば，その脱炭酸によってはプルプロキサンチン(IV) が生成するは ずであるからり，その脱炭酸を行なってみた。

2.2.1 の.色素結晶約 $20 \mathrm{mg}$ を小試験管に入れ，砂汭上で注意 してその熔融点以上に加熱すると分解がおこって発泡が認めら れ，熔融物は一部は炭化し，一部は昇華して器壁に付着する。こ の分解生成物中のアセトン可溶のものを抽出し，アセトンを蒸発 させたのち, 無水酶酸 $2 \mathrm{~m} l$ と数滴の浱硫酸を加えて常温でアセ チル化を行ない, 反応液を冷水で薄め析出する沈殿をあつめ,水， 60\%×タノールで洗浄してから，含水アセトンをもちいて再結晶 し淡黄色の針状結晶をえた。この結晶の融点は $183^{\circ} \sim 184^{\circ} \mathrm{C} て ゙$, Liebermann $n^{5)}$ の方法にしたがって，プルプリンをアルカリ性塩 化第一スズで還元してつくったプルプロキサンチンのジアセチル 化合物の融点 $\left(183^{\circ} \sim 184^{\circ} \mathrm{C}\right.$, 文献值 $\left.183^{\circ} \sim 184^{\circ} \mathrm{C}\right)$ に一致し, 混融しても融点の低下は認められなかった。

以上の結果から，Y色素の脱炭酸生成物はプルプロキサンチン (IV) と同定できる。

\subsection{R色素の単離とその確認}

2.2 の酢酸ナトリウム抽出後のエーテル層はなお橙色を呈して いるが, この色素は $2 \%$ 炭酸水素ナトリウム水溶液で反復抽出を 行なうと,ほとえどが水層に移行する。

この炭酸水素ナトリウム抽出液を $6 \mathrm{~N}$ 硫酸で強酸性にして 1 晚 放置すると，赤橙色の沈殿を生ずる。この沈殿を熱メタノールに 溶解し，水で希釈して $65 \%$ メタノ一ル溶液にすると沈殿を生成 するから，いったん加温して溶解したのち，放冷すると赤色針状

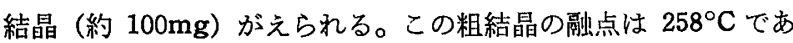
るが，これにブタノール・酢酸・水を溶媒とするペーパークロマ トグラフィーを試みると，単一の赤色ハン点だけが認められ，そ の $R_{f}$ 值は前述の R色素と一致する。

この粗結晶は同じ条件でさらに 1 回再結晶したのち， $2.2 .2 て$ 述べた方法でアセチル化を行なった。アセトンー水を溶媒として 再結晶してえられる結晶の融点は $203^{\circ} \mathrm{C}$ で，プルプリン標品か ら同様にしてえられたトリアセチルプルプリンの融点 $\left(203^{\circ} \mathrm{C}\right.$ ， 交献值 $200^{\circ} \mathrm{C}$ ) に一致し，また，混融試験の結果も同一物質で あることが判明した。

また，この $\mathrm{R}$ 色素のアセチル化物の炭水素分析の結果はつぎの ようにトリアセチルプルプリン $\left(\mathrm{C}_{20} \mathrm{H}_{14} \mathrm{O}_{8}\right)$ の計算值に一致する。

表 $2 \mathrm{R}$ 色素アセチル化物の炭水素分析值（\%)

$\begin{array}{lllcc}\text { 試料 } & 2.6312 \mathrm{mg} & & & \text { 計算値 } \\ \mathrm{CO}_{2} & 6.0450 " & \mathrm{C} & 62.69 & 62.8 \\ \mathrm{H}_{2} \mathrm{O} & 0.9450 " & \mathrm{H} & 4.018 & 3.69\end{array}$

3 総括

この研究はあかね根绝素の抽出を熱硫酸酸性エタノールで行な っているので, 本来グルコシド型のものとして含有されていたか もしれない色素のアグリコンのみを取り出したことになるが，こ こで単離されたものは赤色のプルプリンと黄色のムンジスチンの 二種であった。

植物分類学的に日本あかねの近縁種または同一種とされている

4) H. Schunck, H. Roemer, Ber. deut. Chem. Ges. 10, 172 (1877).

5) Carl Liebermann, Ann. Chem. Liebigs. 183, 213 (1876). 
R. cordifolia L., R. munjista Rox.6) たも, プルプリンとムン ジスチンの両者が含まれていることが報告されており，著者の研 究結果は植物分類学的な近縁関係を，化学成分の立場からも支持 する一查証を与えたことになる。

本研究にあたり,種々御指導いただいた京都大学田中正三教授,
ならびに試料を提供された大阪学芸大学上村六郎教授に梁く感謝 の意を表する。

6) A. G. Perkin, A. E. Everest, "The Natural Organic Colouring Matters," p. 41 43 (1918), Longmans Green Co., London.

\section{Nenitzescu 反 応}

( 昭 和 36 年 6 月 13 日 受理 )

湯川泰秀・花房昭静†

環状不飽和炭化水素と塩化アシルの塩化アルミニウムによる縮合反応で溶媒にシクロヘキサンを用いると, 中間に生成する $\beta$ -

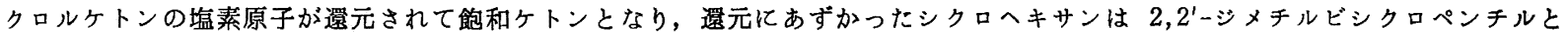
$2,3^{\prime}$-ジメチルビシクロペンチルになるととな明らかにした。

シクロヘキセンと塭化アセチルを二硫化炭素を溶媒として塩化 アルミニウムで縮合させると，2-クロル-1-アセチルシクロヘキ サンが得られることは古くから知られている1。

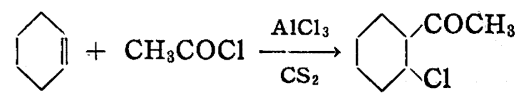

この反応で溶媒の二硫化炭素をシクロヘキサンにかえ, 塩化ア ルミニウムを 2 当量もちいるとアセチルシクロヘキサンが得られ $ろ^{2)}$ 。

$$
\widehat{\mathrm{CH}_{3} \mathrm{COCl}} \underset{\mathrm{C}_{6} \mathrm{H}_{12}}{\stackrel{2 \mathrm{AlCl}_{3}}{\longrightarrow}}
$$

この方法は環状不飽和炭化水素と塩化アシルとの縮合にもちい られ, Nenitzescu 反応と呼ばれている。

Nenitzescu 反応ではあきらかに溶媒のシクロヘキサンが還元 䯇として作用しているが，飽和炭化水素がこのように働く例はほ かにはみられず興味深い*1。

そこでまず一般にクロルケトンが塩化アルミニウムとシクロヘ キサンで還元されるかどうかをしらべてみた。 $\omega$ オクロルアセト フェノン， $\beta$-クロルプロピオフェノンはいずれも反応せず，そ れぞれ 100\% および $85 \%$ 回収され， $\alpha$ ークロルプロピオフェノ ンでは 60\% 回収されるほか高沸点物が約 20\% 生じるが, いず れの場合にも還元生成物は得られなかった。 $\beta$ ークロルブチロフ エノンの場合には $77 \%$ の収率で $\alpha, \beta$ 一不飽和ケトンが得られ， このときも容易に還元がおこらないことがわかった。

しかし, シクロヘキセンと塩化ベンゾィルを二硫化炭素中で 2 当量の塩化アルミニウムをもちいて縮合させ，そののち二硫化炭 素を傾斜して除き，溶媒としてシクロヘキサンを加えて加熱反応 させると，ベンゾイルシクロヘキサンが $26 \%$ 収率で生成した。 二硫化炭素中の反応では 2-クロル-1-ベンゾイルシクロヘキサン

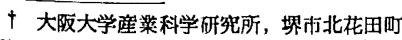

1) G. Darzens, H. Rost, Compt. rend. 150, 707 (1910); 151, 758 (1911).

2) C. D. Nenitzescu, J. P. Cantuniari, Ann. 510, 269 '(1934); C. D. Nenitzescu, E. Cioranescu, Ber. 69 B, 1820 (1936).

*1 塩化アシルはアルデヒドに遇元される. C. D. Nenitzescu, Ann. 191, 189 (1931).
の塩化アルミニウム付加物ができているはずであるから, このも のがシクロヘキサンによって還元されたのであろう。

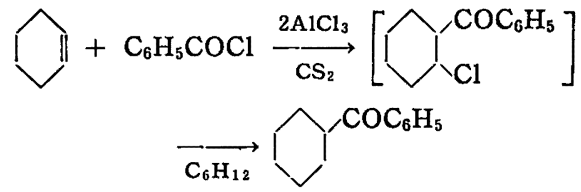

また溶媒を二硫化炭素からべンゼンにかえて反応させると，4フェニル置掺体が得られることもわかっているかから，この中間 体である $\beta$-クロルケトンの塩素原子は不安定で, 前に述べた鎖 状一級および二級炭素原子に結合している塩素原子よりもいっそ う還元されやすい状態にあると考えられる。

鎖状飽和炭化水素と塩化アシルを塩化アルミニウムで縮合させ ると，異性化をともない三級炭素原子を持つ飽和ケトンが生成す る3,4)。たとえば， $n$-ヘキサンと塩化アセチルと塩化アルミニウ ムとの反応では 2-メチル-3-アセチルーペンタンが得られるい。 れらの反応で中間にできると考えられる $\beta$-クロルケトンでは， いずれもその塩素原子は三級炭素原子に 結合していると考えら れこのような塩素原子は環状化合物の二級炭素原子に結合して いる塩素原子と同じように還元されやすいのであろう。

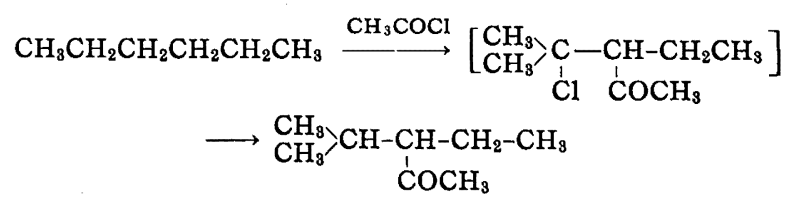

他方還元にあずかったシクロヘキサンは， 2 量体または 3 量体 となり，もちいた塭化アシルのモル数の 70９0\% の収率で bp $200^{\circ} \mathrm{C}$ 以上の液体として得られる。この液体の主成分は bp $213^{\circ}$ 〜214 ${ }^{\circ} \mathrm{C}$ で, その分析值は $\mathrm{C}_{12} \mathrm{H}_{22}$ に一致する。またセライトを 担体としたシリコングリースを吸着䯇とし，ヘリウムをキャリャ ガスとして $155^{\circ} \mathrm{C}$ でガスクロマトグラフィーを行なうと, 図 1 のように主として 2 成分の混合物であることがわかった。この2

3) C. D. Nenitzescu, I. P. Gavat, Ann. 519, 260 (1935); W. S. Johnson, R. D. Offenhauer, J. Am. Chem. Soc. 67, 1045 (1945),

4) C. D. Nenitzescu, I. P. Cantuniari, Ber. 65B, 1449 (1932); C. D. Nenitzescu, I. Chicos, ibib. 88B, 1584 (1935). 